Article

\title{
On-Grid Solar PV versus Diesel Electricity Generation in Sub-Saharan Africa: Economics and GHG Emissions
}

\author{
Saule Baurzhan ${ }^{1, *}$ and Glenn P. Jenkins ${ }^{1,2}$ \\ 1 Department of Economics, Eastern Mediterranean University, Famagusta 99450, Turkey \\ 2 Department of Economics, Queen's University, Kingston, ON K7L 3N6, Canada; jenkins@econ.queensu.ca \\ * Correspondence: saule.baurzhan@gmail.com; Tel.: +90-542-8571-299
}

Academic Editors: Jiawei Gong, Qiquan Qiao, Zhengping Zhou, Tingting Xu, Mao Liang and Wenfeng Zhang Received: 17 January 2017; Accepted: 27 February 2017; Published: 3 March 2017

\begin{abstract}
Many power utilities in sub-Saharan Africa (SSA) have inadequate generation capacity, unreliable services, and high costs. They also face capital constraints that restrict them from making the investments necessary for capacity expansion. Capacity shortages have compelled power utilities to use leased emergency power-generating units, mainly oil-fired diesel generators, as a short-term solution. An economic analysis is carried out to compare the economic net present value (ENPV) of fuel savings, as well as the greenhouse gas (GHG) savings, from investing capital in a solar PV power-generation plant with those from investing the same amount of funds into a diesel power plant. The results show that ENPV is negative for the solar PV plant, whereas it has a large positive value for the diesel plant. In addition, the diesel plant would be almost three times as effective in reducing GHG emissions as the same value of investment in the solar PV plant. Even with solar investment costs falling, it will take 12 to 24 years of continuous decline before solar PV becomes cost-effective for SSA. The capital cost of solar PV would need to drop to US\$1058.4 per kW to yield the same level of ENPV as the diesel plant.
\end{abstract}

Keywords: solar PV; diesel electricity generation; greenhouse gas mitigation; cost-benefit analysis; sub-Saharan Africa

\section{Introduction}

It is well known that the power supply in sub-Saharan Africa (SSA) is unreliable. Electrical power outages in SSA countries are woefully high; 13.9 outages per month in Benin, 7.2 in Gabon, and 32.7 in Central African Republic [1]. The levels of system loss vary in SSA from 14.5\% in Angola to $68 \%$ in Swaziland, with the average values ranging between $30 \%$ and $50 \%$, in contrast to the accepted averages of $7 \%-10 \%$ in the developed world [2]. Inadequate power supplies impose heavy losses on the private sector. Recurrent power outages mean serious losses in forgone sales and damaged equipment [3]. Unreliable supplies of electricity by national electric power utilities have forced many users, from households to large enterprises, to invest in backup generators and generate their own electricity [3-6]. Private power-generation units make up to $6 \%$ of total installed capacity in SSA, with the costs of generation varying between US $\$ 0.3$ and 0.7 per $\mathrm{kWh}$, which is often three times higher than buying the electricity from the public grid [5,7].

Capacity shortages have compelled power utilities to use leased emergency power-generating units, mainly oil-fired diesel generators, to meet the suppressed demand for electricity. Countries enter into short-term leasing contracts, which are expensive $[3,8]$. The costs of these contracts may approach $3 \%-4 \%$ of the GDP in some countries [9]. An estimated $750 \mathrm{MW}$ of emergency generation is currently operating in SSA. In some countries the emergency generation capacity represents a considerable part 
of the national installed capacity. For example, in Angola it has accounted for $18.1 \%$ of the total installed capacity in the country, in Ghana 5.4\%, in Rwanda 48.4\%, and in Uganda 41.7\% [3]. Undoubtedly, the economic costs of inadequate power supplies in the short term are the cost of running backup generators, forgone production due to power outages, payments to leased emergency generation units, and, in the long-run, a lower rate of economic growth $[3,10]$. For those countries that are facing a power crisis, leasing emergency power-generation units may seem like a rapid and effective solution, yet it would divert scarce budgetary resources from long-term power sector investments, reducing the ability of utilities to finance future investments [3]. The deficient power sector infrastructure is one of the major constraints on the economic development of the region [11].

These emergency power-generating units can be installed in a few weeks and then returned back to the private provider after being leased for up to five years or sometimes longer. This is not the only reason for the increased use of diesel power plants. Contemporary diesel power plants are characterized by high fuel efficiency (even at low-capacity utilization), with wide fuel and operational flexibility, high reliability and security, rapid start-up and black-start capabilities, and the modular concept for flexible capacity expansion [12,13]. Since 1897, when the first diesel engine that was used to generate electricity passed the engine test successfully and demonstrated an efficiency of $26.2 \%$, the efficiency of diesel engines has been improved significantly, and presently it ranges between $42 \%$ and $52 \%$, depending on the engine type [14].

However, some SSA countries have ambitious goals for increasing the share of renewable energy generation, especially of grid-connected solar photovoltaic (PV) technology. Electricity-generation technologies that are renewable in nature are appealing to many developing countries, including some SSA countries. For example, Cape Verde is planning to increase the share of renewable energy generation to $50 \%$ by 2020 , Mauritius to $65 \%$ by 2028, and Madagascar to $75 \%$ by 2020 [15]. The National Energy Plan for Kenya outlines the expectation for installed PV capacity to increase to $100 \mathrm{MW}_{\mathrm{p}}$ in 2016, to $200 \mathrm{MW}_{\mathrm{p}}$ in 2022, and to $500 \mathrm{MW}_{\mathrm{p}}$ in 2030 [8]. Solar PV plants can be installed quickly and have the potential to attract subsidized financing from donors. Some utility-scale solar PV projects have already been developed, and others are under way. For instance, Masdar built a $15 \mathrm{MW}$ solar PV power plant in the Islamic Republic of Mauritania in 2013. This is the first utility-scale solar power installation in Mauritania. In 2014, Solar Reserve announced the completion of South Africa's 96 MW Jasper solar PV power plant, and this is now fully operational. Scatec Solar has won a contract from the Ghanaian government to build a $50 \mathrm{MW}$ solar PV power plant in the country. The project was scheduled to become operational by 2015. Recently solar PV system costs have been decreasing rapidly worldwide. This decrease in solar PV system costs is expected to continue in the future, although at a slower rate.

The aim of this paper is to investigate the feasibility of solar PV technology in SSA countries, where the majority of power utilities lack generation capacity. Furthermore, because of a capital constraint over an extended period of time, much of the installed thermal generation capacity has become depreciated and very fuel inefficient. An economic analysis is carried out to compare the savings in fuel and greenhouse gas (GHG) emissions from investing capital in solar PV power-generation plants with those from investing the same amount of funds into modern fuel-efficient diesel power plants. A comparison is made of the economic net present value (ENPV) of the fuel savings versus the capital cost of the solar plant. A similar analysis is carried out for the same investments made in the diesel power plant using heavy fuel oil (HFO) as fuel. To the best of the authors' knowledge, this is the first economic analysis that examines the feasibility of investing in on-grid solar PV electricity generation as compared to diesel electricity generation in the context of SSA.

Due to the intermittency of the energy source, solar PV plants without storage cannot be dispatched by the system operator, and, hence, additional investments in capacity are required to maintain the system reliability. Thus, a solar PV plant with a $20 \%$ capacity factor can actually replace much less generation capacity per MW than a third of a diesel plant with the same MW size but with a $60 \%$ capacity factor, if system reliability is to be maintained [16]. Moreover, currently the electricity 
storage costs are not yet economically viable. Therefore, it is not advisable to introduce a solar PV facility into a power system that is already facing problems of inadequate power supply. A solar plant is not going to add significantly to the capacity of a power system that lacks capacity; neither is it going to improve the reliability of the power system. This is the most important difference between investing in solar PV plants and investing in diesel power plants. Energy analysts in SSA need to pay close attention to this issue when the systems already lack sufficient generation capacity and need to run emergency power-generating units.

A sensitivity analysis is carried out for alternative future world crude oil prices to see how these affect the returns on investment for both plant types. In addition, a sensitivity analysis is carried out for different levels of capital costs of solar PV to find the level at which solar PV would become the preferred option. A calculation is made for how long it would take for solar PV plants to become as competitive as diesel plants and at what level the social cost of carbon needs to be priced for the solar PV project to become attractive.

\section{Methodology}

This study examines a small power system in SSA with a total nominal generation capacity of about $1000 \mathrm{MW}$, consisting of open-cycle gas turbine (OCGT) power plants for base load and diesel power plants for peak load, each fueled by HFO. Of the 48 countries of SSA, 26 have installed a generation capacity of less than $500 \mathrm{MW}$. A total of seven countries have installed a capacity of 500 to $1000 \mathrm{MW}$, while 13 countries have a generation capacity of between 1000 and $5000 \mathrm{MW}$. Two countries, Nigeria and South Africa, have installed a capacity of 9951 and 44,283 MW, respectively. In terms of electricity consumed, 24 of the countries in SSA consume less than 1 TWh of electricity, seven countries consume between 1 and 2 TWh, and 13 countries consume between 2 and 10 TWh and there are four countries, Mozambique, Nigeria, South Africa, and Zambia, with consumptions of 12, 24,212 , and $11 \mathrm{TWh}$, respectively [17]. The generation capacity of the grid-based system is taken as $1000 \mathrm{MW}$ in order to be descriptive of situations where utility-scale solar PV projects are actually being proposed and implemented. HFO was chosen as a fuel for these power plants due to its ease in terms of transportation, and the fact that the vast majority of power plants (both gas turbine and diesel) in Africa are using HFO or diesel rather than cheaper, but not available, natural gas [18].

\subsection{Data Specifications of the Solar PV Plant}

The grid-connected solar PV plant envisioned in this study has a generation capacity of $30 \mathrm{MW}$, with an estimated cost of US $\$ 2.8$ million per MW, making a total investment cost of US\$84 million. The capital cost per MW for installed solar PV generation for this typical SSA country is estimated as the average cost for such plants being built and/or proposed by independent power producers (IPPs) in 2013-2015. The projects are in Burkina Faso (Zagtouli, 30 MW; Windiga, 22 MW), Egypt (Terra Sola, 2 GW), Ghana (Scatec, 50 MW; Blue Energy, 155 MW), Kenya (Canadian Solar, $50 \mathrm{MW}$ ), Mauritania (Masdar, $15 \mathrm{MW}$ ), Rwanda (Goldsol II, $10 \mathrm{MW}$; Scatec, 8.5 MW), and South Africa (Jasper Solar, 96 MW; SunEdison, 60 MW; Scatec, 75 MW, 40 MW) [8,19-31]. For operating and maintenance $(\mathrm{O} \& \mathrm{M})$ costs, the world average estimate of $1.5 \%$ of the total initial investment cost of the PV system is employed [32].

The extra total grid-level system cost necessitated by the introduction of solar PV generation is missing. In the absence of such studies for Africa, the estimate made for EU countries of US $\$ 11.91$ (EUR 8.97) per MWh is taken as an approximate estimate of the total grid-level system cost of solar PV [33]. The grid integration cost per MWh of solar generation is for the lowest level (2\%) of PV penetration.

The size of this solar plant is typical of many projects that are being proposed for countries in SSA today. This proposed plant will be connected to the electricity grid of the country. It is assumed that the construction period will be one year for a solar PV plant and that it will have an operating life of 25 years. Annual degradation is assumed to be $0.6 \%$. The annual solar radiation on angled 
panels is taken as $2023 \mathrm{kWh} / \mathrm{m}^{2}$ per year. This value is calculated by the authors as a yearly average irradiation on optimally inclined modules for SSA countries. The average radiation values for the period 1985-2004 are taken from the PVGIS-Helioclim database provided by the European Commission, Joint Research Centre, Institute for Energy and Transportation, Renewable Energies Unit. The power plant performance ratio is $75 \%$.

The capacity factor is the ratio of the actual annual MW hours of electrical energy production per MW of capacity of a power plant divided by $8760 \mathrm{MWh}$. The higher the capacity factor of a new plant, the greater the amount of emissions reduced per MW of new capacity, ceteris paribus. Solar PV plants can only reduce GHG emissions of the overall generation system when they are producing electricity, i.e. when the sun is shining, which is only a proportion of the time [16]. Solar PV facilities have a capacity factor of $17.3 \%$ in SSA. Although this is a very high value compared to those found anywhere in Europe or in some other parts of the world, it is much lower than the capacity factors of diesel power plants. The capacity factor of a diesel power plant was assumed to be $66 \%$ in this analysis. The new diesel plants will reduce fuel use and emissions per MW of new capacity because they are more efficient than the existing plants that they are replacing on a one for one $\mathrm{kWh}$ basis. There is a marginal saving of fuel for each $\mathrm{kWh}$ produced by the new plants. The higher capacity factor of the diesel plants as compared to solar PV results in greater overall fuel savings by the new diesel plants than the alternative equivalent cost solar PV plant.

The carbon dioxide equivalent is a measure used to compare the emissions from various GHGs based on their global warming potential [34] per $\mathrm{kWh}\left(\mathrm{CO}_{2} \mathrm{E} / \mathrm{kWh}\right)$ of electricity generation. For solar PV technology it is 32 grams [35], assuming an insolation of $1700 \mathrm{kWh} / \mathrm{m}^{2} /$ year, a performance ratio of 0.8 , and a lifetime of 30 years. This value is a lifecycle estimate of GHG per kWh of electricity generation for solar PV systems.

\subsection{Diesel Power Plant Data Specifications}

A calculation is made for the MW of capacity of an HFO-fuelled diesel plant that can be financed for an amount equivalent to that of a $30 \mathrm{MW}$ solar plant costing US $\$ 84$ million. The installed capacity (rated plant capacity) of a diesel plant that can be purchased for US\$84 million at an estimated capacity cost of US $\$ 0.65$ million per MW is $130 \mathrm{MW}$. The capital cost per MW for installed diesel generation for this typical African country is taken as an average of the costs given for different countries in studies by Deichmann et al. (2010) [36], Lazard (2015) [37], and Pauschert (2009) [38]. The operating life of the diesel plant is assumed to be 25 years, the same as for the solar PV plant. The construction period for the diesel plant will be also one year, although a shorter installation period is possible [13].

The energy transformation efficiency of the diesel plant is assumed to be $42 \%$ [14]. The operating efficiency parameters used for the diesel plants are all conservative values and benchmarked on values used in professional feasibility studies where significant grid connected diesel generation investments are being planned. For example, see the FICHNER report on Power Systems Interconnection between the Cyprus Turkish Electricity Authority (KIB-TEK) and the Turkish Electricity Transmission Company (TEIAS) [39]. The other main parameter values are as follows:

- The maximum plant availability will be $91 \%$ of the installed capacity.

- The average availability of the plant will be $89 \%$ of the available capacity after degradation.

- The fuel requirement is $0.21 \mathrm{~L}$ per $\mathrm{kWh}$.

- The annual increase in fuel requirement is $1 \%$.

- The capacity degradation factor (annual deterioration) will be $1 \%$ of the maximum available capacity.

The fixed O\&M cost is high. It is estimated at US\$15 per $\mathrm{kW}$-year [37]. The variable (non-fuel) O\&M cost of the diesel plant is assumed to be equal to that of existing OCGT plants, and it is estimated at US $\$ 4$ per MWh [40]. The total grid-level system cost of the diesel plant is taken as US $\$ 0.56$ per MWh. 


\subsection{Other Technical Specifications}

Given the non-dispatchable nature of the solar plant, its operation will result in a reduction in generation by the open-cycle and diesel power plants. Hence, in this analysis the amount and the value of the fuel savings are computed on the fuel efficiency of the open-cycle and diesel power plants of approximately $0.246 \mathrm{~L}$ of HFO per $\mathrm{kWh}$. For the purposes of this analysis, the assumption made here is that fuel efficiency in terms of HFO use by the highest running cost diesel and OCGT plants are the same per kWh. In most of the smaller utilities in SSA, it will be largely the most inefficient diesel plants that will be cut back in operating time when a more efficient diesel plant or a solar PV plant is introduced. Owing to the degradation of the existing plants, the annual fuel consumption per $\mathrm{kWh}$ will increase by $1 \%$ per year.

Oil price projections are based on US $\$ 454$ per tonne (US\$71.11 per barrel), which corresponds to the average price for HFO over the past 10 years. The current HFO price is US\$ 171 per tonne (US\$ 26.79 per barrel) [41]. Since the projected benefits and costs of the power plants will be spread over a 20-year period, the average oil price for the last 10 years is taken as an estimate of oil price. For this analysis, the real price of crude oil is held constant at this level over the life of the plants. Hence, the delivered cost of HFO will average US $\$ 0.78$ per L, expressed in 2016 prices.

The carbon dioxide equivalent per kWh of electricity generation using HFO is 778 grams. This value is a lifecycle estimate of GHG per kWh of electricity generation using HFO for various types of generators and turbines [42]. The lifecycle estimate of GHG per litre of burning HFO to generate electricity is $3.126 \mathrm{~kg}$. This value is obtained by using $\mathrm{CO}_{2}$ emission factors based on fuel mass or volume, $\mathrm{CH}_{4}$ and $\mathrm{N}_{2} \mathrm{O}$ emission factors by fuel type and sector [43], and Global Warming Potential (GWP) factors [44]. Only $\mathrm{CO}_{2}, \mathrm{CH}_{4}$, and $\mathrm{N}_{2} \mathrm{O}$ gases are used in calculating $\mathrm{CO}_{2} \mathrm{E}$ because over $99 \%$ of the total $\mathrm{CO}_{2} \mathrm{E}$ is due to $\mathrm{CO}_{2}$ emissions [43], and other GHGs, such as HFCs, are used as refrigerants, while PFCs and SF6 are used as manufacturing aids in the metal and semi-conductor industry [44]. The assumption made here is that the lifecycle estimate of GHG per litre of burning HFO to generate electricity will be the same for various types of generators and turbines except for the difference in the energy transformation efficiency.

The gross calorific value of HFO is $41.73 \mathrm{MJ} / \mathrm{L}$ [45]. The social cost of carbon emissions (SCC) is taken to be US $\$ 39$ per tonne for 2015 . There is also an upward trend in the SCC of $1.92 \%$ a year, as proposed by [46].

\subsection{Economic Benefit Calculation}

Solar generation does not eliminate chronic blackouts and brownouts in a system that already has a reserve deficit, as it does not permanently increase the capacity of the system at peak hours. For some daytime hours during the year there will be no sunshine and, hence, no electricity generated. Solar generation replaces the electricity generated by the thermal plants, hence saving fuel. The main benefits of the solar PV plant are the savings on the amount of fuel and the O\&M costs of the thermal plant, whose electricity generation it replaces. In this case, the solar PV plant is replacing generation by the OCGT and diesel plants.

A comparison is made in terms of ENPV as well as GHG savings if the same amount of scarce capital were invested in a solar PV facility as in diesel power generation. To make this analysis possible, the expected energy output for each type of power plant is calculated using the parameter values given in Sections 2.1-2.3. The amount of electricity generated annually by the solar PV system, $E_{S}$ $(\mathrm{kWh})$, is calculated using the following equation:

$$
E_{s}=P_{k} \times P R \times G
$$

where $P_{k}$ is the installed peak power, measured in watt-peak $\left(W_{p}\right), P R$ is the system performance ratio, and $G$ is the yearly sum of global irradiation on a tilted plane of the PV module ( $\mathrm{kWh} / \mathrm{m}^{2} /$ year) [47]. The performance ratio (PR) is the ratio between the actual and theoretical energy outputs of a solar 
PV plant. The closer the PR value is to $100 \%$, the more efficiently the respective PV plant is operating. The amount of electricity generated annually by a diesel plant, $E_{d}(\mathrm{kWh})$, is calculated using the following equation:

$$
E_{d}=N A C \times P L F \times h
$$

where NAC is the net available capacity for sale in watts (gross available capacity minus auxiliary usage). The gross available capacity is the available capacity after degradation multiplied by the availability factor. PLF is the plant load factor, and $h$ is the number of hours in a year.

The amount of fuel saved and GHG emissions avoided are calculated on the basis of the energy output estimated previously. The amount of fuel saved by the solar PV plant, $F S_{s}(\mathrm{~L})$, is measured by the equation:

$$
F S_{s}=E_{s} \times f_{e x}
$$

where $f_{e x}$ is the fuel requirement needed to generate $1 \mathrm{kWh}$ of energy by existing diesel and thermal plants $(\mathrm{L} / \mathrm{kWh})$. The amount of fuel saved by a diesel plant, $F S_{d}(\mathrm{~L})$, is measured by the equation:

$$
F S_{d}=E_{d} \times\left(f_{e x}-f_{d}\right)
$$

where $f_{d}$ is the fuel requirement needed to generate $1 \mathrm{kWh}$ of energy by a diesel plant $(\mathrm{L} / \mathrm{kWh})$ $\left(f_{d}=\frac{3.6 \mathrm{MJ}}{\text { Energy transformation efficiency }(\%) \times \text { Fuel heat content }\left(\frac{\mathrm{MI}}{\text { litre }}\right)}\right.$, because $\left.1 \mathrm{kWh}=3.6 \mathrm{MJ}\right)$.

The amount of GHG emissions avoided by a solar PV plant is measured in kilograms and calculated using the following formula:

$$
G H G e=E_{s} \times\left(m_{k W h}^{\text {fossil fuel }}-m_{k W h}^{\text {solar }}\right)
$$

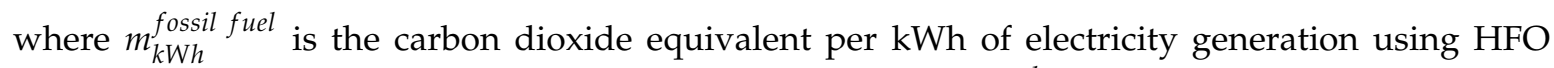
$\left(\mathrm{kg} \mathrm{CO} 2 \mathrm{E} / \mathrm{kWh}\right.$ ) for various types of generator and turbine, and $m_{\mathrm{kWh}}^{\text {solar }}$ is the carbon dioxide equivalent per $\mathrm{kWh}$ of electricity generation for solar PV technology $\left(\mathrm{kg} \mathrm{CO}_{2} \mathrm{E} / \mathrm{kWh}\right)$. The amount of GHG emissions avoided by a diesel plant is measured in kilograms and calculated thus:

$$
\text { GHGe }=F S_{d} \times m_{\text {litre }}
$$

where $m_{\text {litre }}$ is the carbon dioxide equivalent per litre of fossil fuel burned $\left(\mathrm{kg} \mathrm{CO}_{2} \mathrm{E} / \mathrm{L}\right)$.

When there are significant power outages, more electricity will be supplied to meet the suppressed demand during these peak periods. These increased sales will not be saving petroleum and GHG emissions but will be providing additional electricity to be consumed. If both technologies are supplying electricity during these peak periods, then the estimates of fuel savings would be somewhat overstated. While on a per kWh basis, the overstatement of fuel savings would be greater for the additional consumption being supplied by the solar PV plant; it is, however, more likely that a larger quantity of the suppressed consumption will be supplied by the new diesel generators as they do not have the reliability problems associated with the solar PV plant.

The expected economic benefit of solar PV and diesel plants is calculated using a cost-benefit analysis approach, making comparisons between the scenarios with and without the projects. Economic benefits, costs, and net present value (NPV) for each plant type can be expressed by the following equations:

$$
\begin{gathered}
N P V=\sum_{t=0}^{26}(1+E O C K)^{-t} \times\left(E B_{t}-E C_{t}\right) \\
E B_{t}=F S_{t} \times P_{f t}+S O M_{t}+a \times G H G e_{t} \times S C C_{t} \\
E C_{t}=I_{t}+F O M_{t}+V O M_{t}
\end{gathered}
$$


where $E B_{t}$ and $E C_{t}$ are the economic benefits and costs of the plant, $P_{f t}$ is the economic cost of fuel per litre, $S O M_{t}$ is the savings on the variable (non-fuel) O\&M cost of the plant it replaces, $S C C_{t}$ is the social cost of carbon per tonne, $I_{t}$ is the investment cost of the plant, FOM ${ }_{t}$ is the fixed O\&M cost of the plant, and $V O M_{t}$ is the variable O\&M cost of the plant, all at time $t$ and in US dollars. EOCK is the economic opportunity cost of capital (\%). A $12 \%$ economic discount rate is used in this study. This is the discount rate used by international institutions such as USAID and the African Development Bank in the economic analysis of their investment operations in Africa. In addition studies have been carried out to estimate the economic opportunity cost of capital (economic discount rate for countries in Africa) that generally support the use of a $12 \%$ discount rate. The results are $11 \%$ for South Africa [48], $12 \%$ for Kenya [49], and 13\% for Rwanda [50]. The countries that are more critically short of capital resources are likely to be facing an even higher economic opportunity cost of funds. $F S_{t}$ is the amount of fuel saved by the plant in litres at time $t$. GHGe $e_{t}$ is the amount of GHG emissions avoided by the plant in tonnes at time $t$, and $a$ is a coefficient equal to 0 in analysis from the country's point of view and to 1 from the global point of view. Finally, a comparison is made between these two power plants (solar and diesel).

The levelized cost of energy (LCOE) per kWh is estimated for both solar PV and diesel plants using the formula:

$$
\mathrm{LCOE}=\frac{\sum_{t=1}^{n} \frac{E C_{t}}{(1+r)^{t}}}{\sum_{t=1}^{n} \frac{E_{t}}{(1+r)^{t}}}
$$

where $E_{t}$ is the quantity of electricity produced in year $t$ in $\mathrm{kWh}, r$ is the discount rate, and $n$ is the economic operational lifetime of the system.

\section{Results}

The following analysis first considers the option of investing in a solar PV plant, which will reduce the level of electricity currently generated by existing diesel and thermal power plants. This is followed by a similar analysis of the investment of the same amount of capital to finance a diesel plant.

\subsection{Economic Evaluation of Solar PV Technology}

Solar generation does not eliminate the chronic blackouts and brownouts in a system that already has a reserve deficit, as it does not permanently increase the capacity of the system at the peak hours. The biggest benefits of the solar PV plant are the savings on the amount of fuel and on the O\&M costs of the old diesel and thermal plants, whose electricity generation it replaces. Table 1 shows the amount of fuel savings, the financial value of the fuel savings, and the amount of GHG emissions avoided.

The timing of the generation could have an impact on the value of the additional capacity. It would occur particularly if the system peak load coincided with the maximum generation hours of the solar PV generation. Average daily load and annual load duration curves were constructed to see the pattern of demand for electricity in SSA by analyzing electricity loads in 15 different countries for which data were available. The residual load duration curve was also examined to see how solar PV fits the system by collecting the data from European Commission, Joint Research Centre (Photovoltaic Geographical Information System) on solar irradiation for SSA countries. Based on the analysis, the daily peak occurs during the evening hours in SSA countries, whereas the major share of the solar PV electricity is generated during the daytime period when the radiation is the highest. In no country did the solar PV electricity generation coincide with the system peak. Solar PV basically services the intermediate load periods that occur during the daytime. It is likely that the variable costs of these intermediate loads might be somewhat higher than some of the off-peak generation being replaced by the diesel; however, the diesel generation will cover the peak periods as well as the intermediate and off-peak periods. Therefore in the case of these fairly homogeneous thermal generation systems, it would appear safe to conclude that the timing of solar PV generation as compared to the diesel generation will not appreciably affect the overall impact on the conclusions drawn from this analysis. 
Table 1. Fuel savings and revenue from solar photovoltaic (PV) power generation.

\begin{tabular}{ccccccc}
\hline Year & $\mathbf{0}$ & $\mathbf{1}$ & $\mathbf{2}$ & $\mathbf{3}$ & $\ldots$ & $\mathbf{2 5}$ \\
\hline Total electricity production (MWh) & 0 & 45,518 & 45,244 & 44,973 & $\ldots$ & 39,396 \\
Total fuel savings in (litres 000) & 0 & 11,197 & 11,241 & 11,286 & $\ldots$ & 12,306 \\
Financial value of total fuel savings (US\$000) & 0 & 8713 & 8747 & 8781 & $\ldots$ & 9575 \\
GHG emissions avoided (tonnes) & 0 & 33,956 & 33,752 & 33,550 & $\ldots$ & 29,389 \\
\hline
\end{tabular}

The economic resource flow for the solar PV plant is evaluated in Table 2 from the country's point of view. The ENPV at a real discount rate of $12 \%$ has a negative value of $-\mathrm{US} \$ 28.191$ million and an economic internal rate of return (IRR) of $7.01 \%$.

Table 2. Economic resource flow statement for solar PV power generation from the country's point of view (US\$000).

\begin{tabular}{ccccccc}
\hline Year & $\mathbf{0}$ & $\mathbf{1}$ & $\mathbf{2}$ & $\mathbf{3}$ & $\ldots$ & $\mathbf{2 5}$ \\
\hline Economic value of fuel savings & 0 & 8598 & 8632 & 8666 & $\ldots$ & 9449 \\
Savings on O\&M costs of old diesel and & 0 & 182 & 181 & 180 & $\ldots$ & 158 \\
thermal plants & 0 & 8780 & 8813 & 8846 & $\ldots$ & 9607 \\
Total inflows & 0 & 1272 & 1272 & 1272 & $\ldots$ & 1272 \\
O\&M cost & 84,780 & 0 & 0 & 0 & $\ldots$ & 0 \\
Capital cost & 0 & 542 & 539 & 536 & $\ldots$ & 469 \\
Grid-level system cost & 84,780 & 1814 & 1811 & 1807 & $\ldots$ & 1741 \\
Total outflows & $-84,780$ & 6966 & 7002 & 7039 & $\ldots$ & 7866 \\
Net resource flow & ENPV (country, US\$000) @ 12\%=-28,191 \\
\hline
\end{tabular}

The economic resource flow for the solar PV plant from a global point of view is estimated in Table 3 by adding in the benefit of reduced GHG emissions. The value of the ENPV improves from -US $\$ 28.191$ million to - US $\$ 16.372$ million, yet it is still negative. The economic IRR has increased to $9.21 \%$.

Table 3. Economic resource flow statement for solar PV power generation from a global point of view (US\$000).

\begin{tabular}{|c|c|c|c|c|c|c|}
\hline Year & 0 & 1 & 2 & 3 & $\ldots$ & 25 \\
\hline \multirow{2}{*}{$\begin{array}{c}\text { Economic value of fuel savings } \\
\text { Savings on O\&M costs of old diesel and } \\
\text { thermal plants }\end{array}$} & 0 & 8598 & 8632 & 8666 & $\ldots$ & 9449 \\
\hline & 0 & 182 & 181 & 180 & $\ldots$ & 158 \\
\hline Economic value of GHG emission reductions & 0 & 1376 & 1394 & 1412 & $\ldots$ & 1879 \\
\hline Total inflow & 0 & 10,156 & 10,207 & 10,258 & $\ldots$ & 11,486 \\
\hline O\&M cost & 0 & 1272 & 1272 & 1272 & $\ldots$ & 1272 \\
\hline Capital cost & 84,780 & 0 & 0 & 0 & $\ldots$ & 0 \\
\hline Grid-level system cost & 0 & 542 & 539 & 536 & $\ldots$ & 469 \\
\hline Total outflows & 84,780 & 1814 & 1811 & 1807 & $\ldots$ & 1741 \\
\hline Net resource flow & $-84,780$ & 8342 & 8396 & 8450 & $\ldots$ & 9745 \\
\hline \multicolumn{7}{|c|}{ ENPV (global, US\$000) @ 12\% = -16,372 } \\
\hline
\end{tabular}

It is hard to justify the introduction of solar PV plants into the electricity-generation system in terms of saving fuel oil by substituting for thermal generation. Even assuming a real price of HFO equal to the average of the past 10 years, the value of the fuel oil saved is much lower than the capital costs of the solar PV systems.

\subsection{Economic Evaluation of Diesel Technology}

A new diesel plant is likely to be the most fuel-efficient plant in the system, generating electricity for the base load. Because the diesel plant is more efficient than the existing diesel and thermal plants, it will save fuel, and, as a consequence, less GHG will be released into the atmosphere. Table 4 
shows the amount of fuel savings, the financial value of the fuel savings, and the amount of GHG emissions avoided.

Table 4. Fuel savings and revenue from diesel power generation.

\begin{tabular}{ccccccc}
\hline Year & $\mathbf{0}$ & $\mathbf{1}$ & $\mathbf{2}$ & $\mathbf{3}$ & $\mathbf{2 5}$ \\
\hline Total electricity production (MWh) & 0 & 749,550 & 742,054 & 734,634 & $\ldots$ & 588,905 \\
Total fuel savings (litres 000) & 0 & 30,430 & 30,427 & 30,424 & $\ldots$ & 30,357 \\
Financial value of fuel savings (US\$000) & 0 & 23,677 & 23,675 & 23,673 & $\ldots$ & 23,621 \\
GHG emissions avoided (tonnes) & 0 & 95,117 & 95,108 & 95,098 & $\ldots$ & 94,889 \\
\hline
\end{tabular}

The main benefits of the diesel plant are the fuel savings that are the result of its energy transformation efficiency. Table 5 reports on the economic resource flow for the diesel plant from the country's point of view.

Table 5. Economic resource flow statement for diesel power generation from the country's point of view (US\$000).

\begin{tabular}{ccccccc}
\hline Year & $\mathbf{0}$ & $\mathbf{1}$ & $\mathbf{2}$ & $\mathbf{3}$ & $\ldots$ & $\mathbf{2 5}$ \\
\hline Economic value of fuel savings & 0 & 23,367 & 23,365 & 23,362 & $\ldots$ & 23,311 \\
Total inflow & 0 & 23,367 & 23,365 & 23,362 & $\ldots$ & 23,311 \\
Operating cost & 0 & 1956 & 1956 & 1956 & $\ldots$ & 1956 \\
Capital cost & 84,780 & 0 & 0 & 0 & & 0 \\
Grid-level system cost & 0 & 420 & 416 & 411 & $\ldots$ & 330 \\
Total outflow & 84,780 & 2376 & 2372 & 2368 & $\ldots$ & 2286 \\
Net resource flow & $-84,780$ & 20,991 & 20,993 & 20,994 & $\ldots$ & 21,025 \\
\hline & ENPV (country, US\$000) @ 12\% $=79,940$ \\
\hline
\end{tabular}

The ENPV of the diesel investment (using a discount rate of $12 \%$ ) is US $\$ 79.940$ million. This is US\$108.131 million more than for the solar PV plant. The economic internal rate of return (EIRR) is $24.67 \%$. This is the type of efficient electricity-generation technology that the electric utilities of SSA countries now need to have more of in order to reduce their overall generation costs.

The economic resource flow for the diesel plant from a global point of view is also estimated, including the GHG damage saved, and the results are shown in Table 6. The ENPV increases further to US $\$ 114.525$ million and the EIRR to $29.57 \%$.

Table 6. Economic resource flow statement for diesel generation from a global point of view including GHG damage mitigation (US\$000).

\begin{tabular}{|c|c|c|c|c|c|c|}
\hline Year & 0 & 1 & 2 & 3 & $\ldots$ & 25 \\
\hline Economic value of fuel savings & 0 & 23,367 & 23,365 & 23,362 & $\ldots$ & 23,311 \\
\hline Economic value of GHG emission reductions & 0 & 3853 & 3927 & 4002 & $\ldots$ & 6068 \\
\hline Total inflow & 0 & 27,220 & 27,292 & 27,364 & $\ldots$ & 29,379 \\
\hline Operating cost & 0 & 1956 & 1956 & 1956 & $\ldots$ & 1956 \\
\hline Capital cost & 84,780 & 0 & 0 & 0 & $\ldots$ & 0 \\
\hline Grid- level system cost & 0 & 420 & 416 & 411 & $\ldots$ & 330 \\
\hline Total outflows & 84,780 & 2376 & 2372 & 2368 & $\ldots$ & 2286 \\
\hline Net resource flow & $-84,780$ & 24,844 & 24,920 & 24,996 & $\ldots$ & 27,092 \\
\hline \multicolumn{7}{|c|}{ ENPV (global, US\$000) @ 12\%=114,525 } \\
\hline
\end{tabular}

These results show that adding a modern diesel plant to a fuel-inefficient thermal generation system is a good investment decision. The amount of electricity generated by a diesel plant with the same capital cost as a solar PV plant is 16 times greater. This has a dramatic positive impact from both the country's and the global point of view. The fuel savings from the diesel plant are 2.6 times greater than those from the solar PV plant. As a consequence, the GHG emissions avoided by the diesel plant are 2.9 times more than those from the solar PV plant. The diesel plant will also improve the reliability 
of the overall system supply because the old diesel and thermal plants that have been displaced can now be used to meet the peak load demands.

The benefits induced by the reliability increase would be realized somewhat by the utility via efficiency gains or factors which lower overall production costs but also by the consumers in the form of reduced frequencies and durations of outages. The methods of economic valuation of these benefits are based on the consumer surveys measuring the revealed preference or stated preferences for enhanced electricity reliability. The benefits are measured by the value consumers place on avoiding outages. The current study does not provide the valuation of the economic benefits associated with reliability due to the difficulties associated with conducting such surveys, especially when one thinks of all the SSA countries. If these benefits were valued and included in this study, they would increase the ENPV of the diesel investment further, making the argument even stronger. This is an important difference between these two investment options to which the electricity policy makers in SSA need to pay close attention.

\subsection{Sensitivity Analysis}

A sensitivity analysis is carried out for a range of HFO prices, ceteris paribus. The results, which are shown in Figure 1, show that the ENPV for the solar PV plant becomes positive only if the inefficient plants it is replacing are using fuel that costs US $\$ 88$ per barrel (US $\$ 562$ per tonne) or more, whereas the ENPV for the diesel plant is positive at any price above US\$26.8 per barrel (US\$171 per tonne).

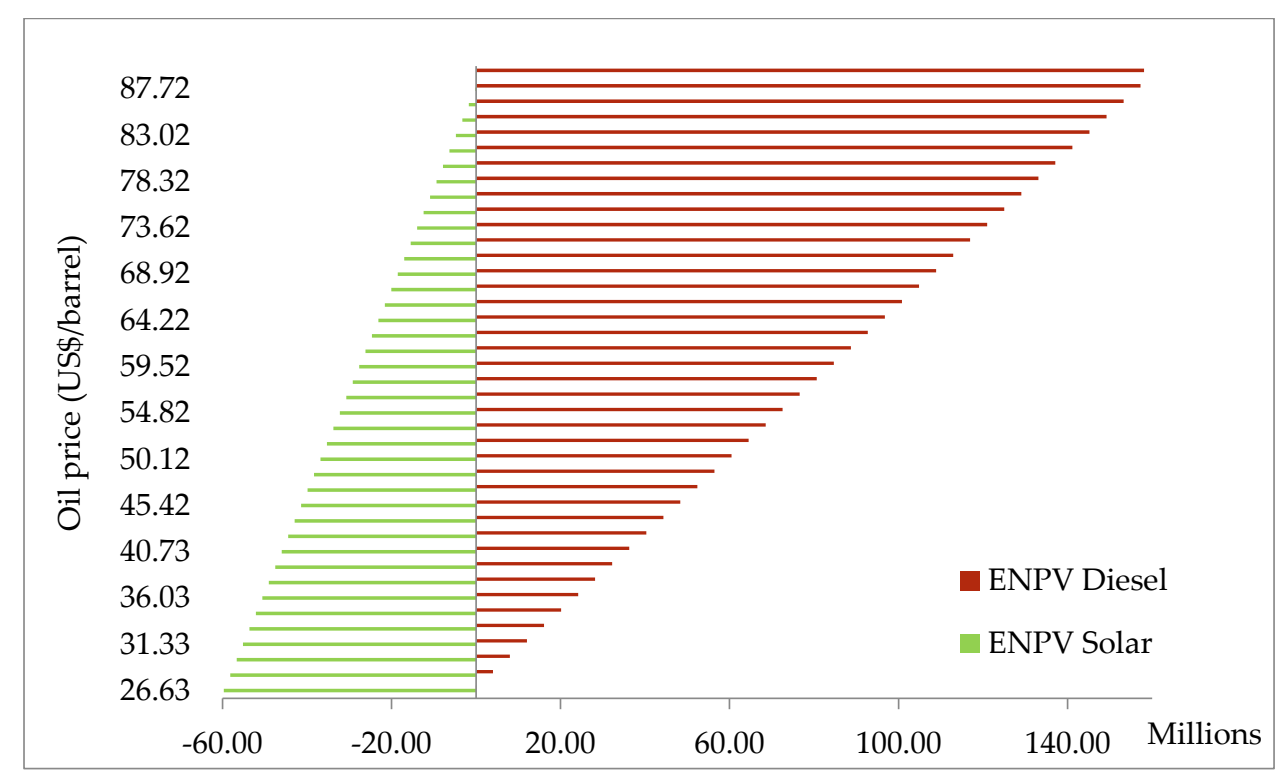

Figure 1. Sensitivity analysis of the economic net present value (ENPV) at $12 \%$ for solar PV and diesel technologies to heavy fuel oil (HFO) prices.

It was shown in Section 3.1 that the solar PV power generation is not competitive if the economic analysis is considered from the country's and the global point of view. What, then, is the level of SCC that would make solar PV power generation break even economically? As can be seen in Figure 2, the ENPV of the solar PV plant becomes positive (as compared to continuing to generate with existing inefficient plants) only at a value of US\$94 per ton for the social cost of carbon. This value is much higher than the estimates of US\$12, 39, and 61 that have been proposed for 2015 by the United States Environmental Protection Agency (EPA) [46] for use in such appraisals. 


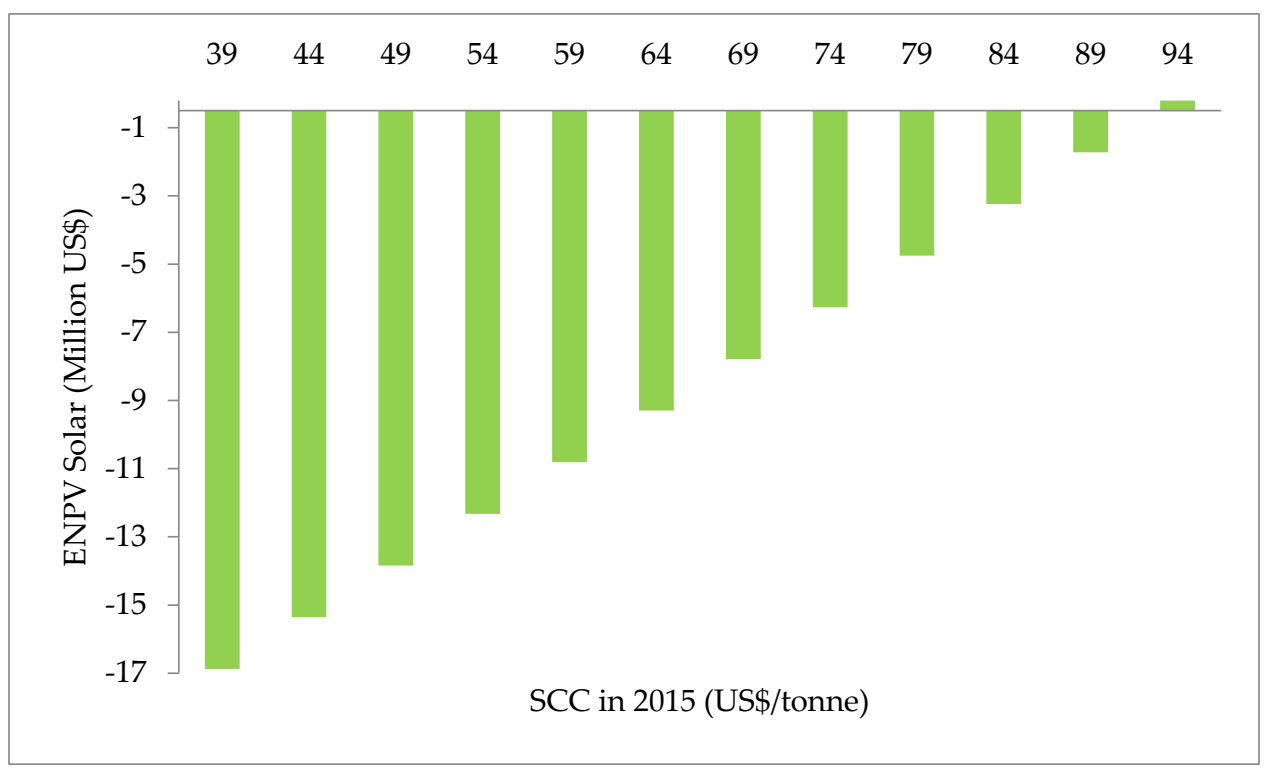

Figure 2. Sensitivity analysis of ENPV at $12 \%$ of solar PV technology to the social cost of carbon emissions (SCC).

The next task is to find the level of capital cost of solar PV that would make the ENPV of the solar PV plant equal to that of the diesel plant, ceteris paribus. When the capital cost of solar PV drops to US $\$ 1058.4$ per MW, the total cost of a 30 MW solar PV plant costs US $\$ 31$ million, and it yields the same level of ENPV (US $\$ 42.893$ million) as if this same amount were invested in the diesel generation plant, ceteris paribus.

\subsection{Scenario Analysis: Reductions in the Cost of Solar PV Technology over Time}

A scenario analysis is undertaken to find out how long it will take for the solar PV plant to become competitive with the diesel plants for electricity generation. Using benchmark utility-scale solar PV system price projections from the National Renewable Energy Laboratory [51] for the period 2010-2020, the average annual expected percentage decrease in overall real system costs is estimated to be $7.67 \%$. Naam (2011) has projected a 7\% decrease in the cost of solar technologies [52]. However, based on solar PV project cost projections from Chase (2013) [53] of Bloomberg New Energy Finance for 2010-2020, the average annual expected percentage decrease in overall real system costs is estimated to be $4 \%$. Therefore, both values are used in the analysis. It is assumed that there will be no change in the real diesel plant's capital costs per MW over time.

The number of years $(n)$ needed for a solar PV plant to have the same ENPV as a diesel power plant when the capital cost of a solar PV plant is now decreasing by $i$ percentage per year is calculated by:

$$
\mathrm{n}=\log _{(1-\mathrm{i})} \frac{C C_{r}}{C C_{\mathcal{C}}}
$$

where $C_{r}$ is the capital cost (reduced) of a solar PV plant per $\mathrm{MW}_{\mathrm{p}}$ that would make the ENPV of the solar PV plant equal to that of the diesel plant, and $C_{c}$ is the current level of capital cost of solar PV plant per $\mathrm{MW}_{\mathrm{p}}$.

Given that the projected percentage decreases in solar PV system costs are $7.67 \%$ and $4 \%$ a year, it is estimated that it will take from 12.3 to 24 years for the solar PV plant to become competitive with the diesel plant, ceteris paribus. As in the analysis reported in Section 3.3, the MW of a diesel plant that would have an equivalent cost to this $30 \mathrm{MW}$ solar plant is also decreased to $48.85 \mathrm{MW}$ to match the drop in the cost of the solar PV plant. 
With falling solar PV system prices, it is not advisable for electric utilities with the characteristics of the one described here to invest in this technology until at least 2030.

\section{Conclusions and Discussion}

This analysis suggests that it is only advisable for SSA countries to invest in such capital-intensive solar PV technologies for on-grid electricity generation if their purchase is being subsidized by multilateral or bilateral donors and if these aid flows are completely tied to this type of technology.

The net fuel savings by the overall electricity-generation system with a new efficient diesel plant are nearly three times greater than those obtained with a solar PV plant. As a result, the amount of GHG emissions avoided by using a diesel plant is almost three times greater than that of a solar PV plant with the same capital cost. It is clear that efficient diesel plants make a much greater contribution to environmental sustainability than does the same investment in solar PV generation. This occurs when both are installed into an overall fuel-inefficient electricity-generation system.

These results show that adding a diesel plant to a fuel-inefficient thermal generation system is a good investment decision. The amount of electricity generated by diesel plants with the same capital cost as a solar PV plant is 16 times greater. Moreover, for the power utilities of SSA with capacity shortages, it is better to invest in diesel power plants rather than to invest in high-capital-cost solar PV power plants or continue leasing emergency power-generating units. These results should be taken into consideration by policymakers when selecting different technology alternatives for electricity generation in SSA.

The modern fuel-efficient diesel plants have a number of advantages that are important in reducing some of the most critical constraints facing the electricity systems of SSA. First, they can be installed quickly and are modular. Second, they are relatively inexpensive, so the financially constrained utilities can increase their generation capacity more rapidly, given their available financing. Third, they are ideally suited to addressing the problems of system stability as the demands for electricity change throughout the day. Fourth, they can utilize a number of types of fuel, in particular both HFO and natural gas, if the latter becomes available in the future. In contrast, solar PV generally causes the overall generation system to become less reliable and represents a costly up-front investment.

It is not advisable in SSA countries, where resources are already scarce, for electric utilities to invest in solar PV systems (unless subsidized from abroad) until solar PV plants become competitive with diesel plants. If unsubsidized, it is the relatively poor consumers of SSA who will pay for these inefficient technological choices, which will also constrain the ability of utilities to expand in the future.

Author Contributions: This paper is a continuation of four year collaborative research effort by Saule Baurzhan and Glenn P. Jenkins in electricity economics. The topic emerged from authors' previous work. Saule Baurzhan completed the research on the specific data required to complete the analysis. The analysis and preparation of the research reports has been a joint effort.

Conflicts of Interest: The authors declare no conflict of interest.

\section{References}

1. World Bank. Africa Development Indicators 2012/13; International Bank for Reconstruction and Development/The World Bank: Washington, DC, USA, 2013.

2. Tallapragada, V.S.N.P.; Shkaratan, M.; Izaguirre, A.K.; Helleranta, J.; Rahman, S.; Bergman, S. Monitoring Performance of Electric Utilities Indicators and Benchmarking in Sub-Saharan Africa; The World Bank: Washington, DC, USA, 2009.

3. Eberhard, A.; Foster, V.; Briceño-Garmendia, C.; Shkaratan, M. Power: Catching up. In Africa's Infrastructure: A Time for Transformation; Foster, V., Briceño-Garmendia, C., Eds.; The International Bank for Reconstruction and Development/The World Bank: Washington, DC, USA, 2010; pp. 181-202.

4. The African Development Bank. South Sudan: An Infrastructure Action Plan, A Program for Sustained Strong Economic Growth; The African Development Bank (AfDB) Group: Tunis-Belvedere, Tunisia, 2013. 
5. Foster, V.; Steinbuks, J. Paying the Price for Unreliable Power Supplies: In-House Generation of Electricity by Firms in Africa; Policy Research Working Paper WPS4913; The World Bank: Washington, DC, USA, 2009.

6. Karakezi, S.; Kimani, J. Status of power sector reform in Africa: Impact on the poor. Energy Policy 2002, 30, 923-945. [CrossRef]

7. Foster, V.; Steinbuks, J. When do firms generate? Evidence on in-house electricity supply in Africa. Energy Econ. 2010, 32, 505-514.

8. UNEP. Prospects for Investment in Large-Scale, Grid-Connected Solar Power in Africa; United Nations Environment Programme (UNEP), RISO Centre: Copenhagen, Denmark, 2014.

9. Eberhard, A.; Foster, V.; Briceño-Garmendia, C.; Ouedraogo, F.; Camos, D.; Shkaratan, M. Underpowered: The State of the Power Sector in Sub-Saharan Africa; Africa Infrastructure Country Diagnostic Background Paper No. 6; World Bank: Washington, DC, USA, 2008.

10. Eberhard, A.; Shkaratan, M. Powering Africa: Meeting the financing and reform challenges. Energy Policy 2012, 42, 9-18. [CrossRef]

11. Foster, V. Overhauling the Engine of Growth: Infrastructure in Africa; Africa Infrastructure Country Diagnostic, World Bank: Washington, DC, USA, 2008.

12. MAN Diesel \& Turbo. Power Plants: Energy Wherever You Need It. Available online: http:/ / mandieselturbo. com/files/news/filesof11510/Brochure_Power\%20Plants.pdf (accessed on 26 June 2015).

13. Wärtsilä. Oil Power Plants, 2013. Wärtsilä Corporation. Available online: http://www.wartsila.com/en $\mathrm{CN}$ /power-plants/smart-power-generation/oil-power-plants (accessed on 29 May 2014).

14. Wärtsilä. Improving Efficiency. 2016. Available online: http://www.wartsila.com/sustainability/ environmental-responsibility/products-and-environmental-aspects/improving-efficiency (accessed on 5 April 2016).

15. The United Nations Environment Programme (UNEP). Financing Renewable Energy in Developing Countries, Drivers and Barriers for Private Finance in Sub-Saharan Africa; Instaprint: Geneva, Switzerland, 2012.

16. Frank, C.R. The Net Benefits of Low and No-Carbon Electricity Technologies; Working Paper 73; Global Economy \& Development at Brookings, The Brookings Institution: Washington, DC, USA, 2014.

17. EIA. International Energy Statistics. US Energy Information Administration (EIA). Available online: http: / / www.eia.gov/ (accessed on 14 February 2017).

18. IMF. Energy Subsidy Reform in Sub-Saharan Africa, Experiences and Lessons; International Monetary Fund, African Department: Washington, DC, USA, 2013.

19. African Review. Scatec Solar to Build 50MW Solar Power Plant in Ghana. Available online: http:/ / www.africanreview.com/energy-a-power/renewables/scatec-solar-to-build-50mw-solarpower-plant-in-ghana (accessed on 26 June 2015).

20. EC. Commissioner Piebalgs to Announce Concrete Projects in Africa to Provide Access to Clean Energy. Available online: http:/ / ec.europa.eu/commission_2010-2014/piebalgs/headlines/news/2012/ 09/20120924_2_en.htm (accessed on 26 June 2015).

21. Electric Light \& Power. Masdar Launches Solar Photovoltaic Plant in Mauritania. Available online: http: / /www.elp.com/articles/2013/04/masdar-launches-solar-photovoltaic-plant-in-mauritania.html (accessed on 26 June 2015).

22. Energiyaglobal. Construction Begins on East Africa's First Utility-Scale Solar Field. Available online: http:/ / energiyaglobal.com/rwanda-field-reaches-financial-close-begins-construction/ (accessed on 26 June 2015).

23. Mugisha, I.R. Investors Plan 10 mw Solar Plant in Kayonza. Available online: http:/ / www.newtimes.co.rw / section/article/2014-05-15/75311/ (accessed on 26 June 2015).

24. OPIC. Spotlight on OPIC Impact Award Winners: SunEdison, The Overseas Private Investment Corporation (OPIC) Blog. Available online: http://www.opic.gov/blog/events/spotlight-on-opic-impact-awardwinners-sunedison (accessed on 26 June 2015).

25. Pincent Masons LLP. European Investment Bank Backs Construction of New Solar Plant in Burkina Faso. Available online: http://www.out-law.com/en/articles/2014/september/european-investmentbank-backs-construction-of-new-solar-plant-in-burkina-faso/ (accessed on 26 June 2015).

26. PVTech. MoU Agreed for 50MW Kenya PV Project. Available online: http://www.pv-tech.org/news/ kenya_signs_mou_for_50mw_with_canadian_consortium (accessed on 26 June 2015). 
27. Renewable-Technology, Terra Sola to Drive Solar Power Growth in Egypt for 2GW. Available online: http:/ / www.renewable-technology.com/news/newsterra-sola-to-drive-solar-power-growth-inegypt-for-2gw-4537552 (accessed on 26 June 2015).

28. Scatec. Scatec Solar Is Selected as Preferred Bidder for 75 MW Solar PV Plant in South Africa. Available online: http://www.scatec.no/no/News/20111209_SSO_project_SA.aspx (accessed on 26 June 2015).

29. SeeNews (2015). Scatec Completes 40-MW Solar Farm in South Africa. Available online: http:// renewables.seenews.com/news/scatec-completes-40-mw-solar-farm-in-south-africa-429164\# (accessed on 26 June 2015).

30. The Financial Times. Blue Energy to Build Solar Site in Ghana. Available online: http://www.ft.com/intl/ cms/s/0/da1e73d0-3d6f-11e2-9f35-00144feabdc0.html\#axzz3dUuNKdWz (accessed on 26 June 2015).

31. Wikipedia. Jasper Solar Energy Project. Available online: https://en.wikipedia.org/wiki/Jasper_Solar_ Energy_Project (accessed on 26 June 2015).

32. Jäger-Waldau, A. PV Status Report 2013; European Commission, DG Joint Research Centre, Institute for Energy and Transport, Renewable Energy Unit: Ispra, Italy, 2013.

33. Pudjianto, D.; Djapic, P.; Dragovic, J.; Strbac, G. Grid Integration Cost of Photovoltaic Power Generation: Direct Costs Analysis related to Grid Impacts of Photovoltaics; Imperial College: London, UK, 2013.

34. OECD. Environmental Indicators for Agriculture_Volume 3: Methods and Results; OECD: Paris, France, 2001; pp. 389-391.

35. Fthenakis, M.V.; Kim, C.H.; Alsema, E. Emissions from Photovoltaic life cycles. Env. Sci. Technol. 2008, 42, 2168-2174. [CrossRef]

36. Deichmann, U.; Meisner, C.; Murray, S.; Wheeler, D. The Economics of Renewable Energy Expansion in Rural Sub-Saharan Africa; Policy Research Working Paper No. 5193; World Bank: Washington, DC, USA, 2010.

37. Lazard. Levelized Cost of Energy Analysis, version 9.0. 2015. Available online: https://www.lazard.com/ media/2390/lazards-levelized-cost-of-energy-analysis-90.pdf (accessed on 26 October 2016).

38. Pauschert, D. Study of Equipment Prices in the Power Sector; Energy Sector Management Assistance Program (ESMAP) Technical Paper 122/09; International Bank for Reconstruction and Development/World Bank Group: Washington, DC, USA, 2009.

39. FICHTNER. Power Systems Interconnection between KIBTEK and TEIAS, Final Study Report, Pre-Feasibility Study. Available online: http://www.kibrispostasi.com/Belgeler/Final_Study_Report_Northern_Cyprus_ Turkey.pdf (accessed on 18 Febraury 2017).

40. MEM. Power System Master Plan 2012 Update; Ministry of Energy and Minerals (MEM): Dar es Salaam, United Republic of Tanzania, 2013.

41. Insee. International Prices of Imported Raw Materials_-Heavy Fuel Oil (Rotterdam)—Prices in US dollars per tonne-FOB-1\% of sulphur. National Institute of Statistics and Economic Studies (Insee). Available online: http:/ /www.insee.fr/en/bases-de-donnees/bsweb/serie.asp?idbank=001642883 (accessed on 28 February 2016).

42. Gagnon, L.; Belanger, C.; Uchiyama, Y. Life-cycle assessment of electricity generation options: The status of research in year 2001. Energy Policy 2002, 30, 1267-1278. [CrossRef]

43. EPA. Direct Emissions from Stationary Combustion Sources; Climate Leaders Greenhouse Gas Inventory Protocol Core Module Guidance, May 2008; US Environmental Protection Agency (EPA): Washington, DC, USA, 2008.

44. CAPP. Calculating Greenhouse Gas Emissions Guide; Canadian Association of Petroleum Producers (CAPP): Calgary, Alberta, Canada, 2003.

45. The Australian Institute of Energy. Energy Value and Greenhouse Emission Factor of Selected Fuels. Available online: http://aie.org.au/Content/NavigationMenu/Resources/EnergyData/Energy_Value_ Greenh.htm (accessed on 29 May 2014).

46. EPA. Fact Sheet: Social Cost of Carbon; United States Environmental Protection Agency (EPA): Washington, DC, USA, 2013.

47. Suri, M.; Huld, T.A.; Dunlop, E.D.; Ossenbrink, H.A. Potential of solar electricity generation in the European Union member states and candidate countries. Sol. Energy 2007, 81, 1295-1305. [CrossRef]

48. Kuo, C.Y.; Jenkins, G.P.; Mphanlele, B. The Economic Opportunity cost of Capital in South Africa. S. Afr. J. Econ. 2003, 71, 523-543. [CrossRef] 
49. Ghanbariamin, R. Estimating the Economic Opportunity Cost of Capital for Kenya. Master of Science Thesis in Economics, Eastern Mediterranean University. Available online: http:/ /i-rep.emu.edu.tr:8080/xmlui/ bitstream/handle/11129/1775/GhanbariaminRoksana.pdf?sequence=1 (accessed on 17 February 2017).

50. Ministry of Finance and Economic Planning/Rwanda. National Parameters. Available online: http:// rwanda-cscf.cri-world.com/NationalParameters.php (accessed on 17 February 2017).

51. Goodrich, A.; James, T.; Woodhouse, M. Residential, Commercial, and Utility-Scale Photovoltaic (PV) System Prices in the United States: Current Drivers and Cost-Reduction Opportunities; Technical Report; National Renewable Energy Laboratory: Springfield, VA, USA, 2012.

52. Naam, R. Smaller, cheaper, faster: Does Moore's law apply to solar cells? Available online: https://blogs. scientificamerican.com/guest-blog/smaller-cheaper-faster-does-moores-law-apply-to-solar-cells/ (accessed on 29 May 2014).

53. Chase, J. PV markets: Status and prospects, geographical segmentation and growth dynamics. In Proceedings of the Global Solar Summit, Shaping the Future of Solar, Milano, Italy, 8-9 May 2013.

(C) 2017 by the authors. Licensee MDPI, Basel, Switzerland. This article is an open access article distributed under the terms and conditions of the Creative Commons Attribution (CC BY) license (http:/ / creativecommons.org/licenses/by/4.0/). 